\title{
Adam Bede and 'the green trash of the railway stall': George Eliot and the lady novelists of 1859
}

Book or Report Section

Accepted Version

Marshall, G. (2018) Adam Bede and 'the green trash of the railway stall': George Eliot and the lady novelists of 1859. In: Gavin, A. E. and de la L. Oulton, C. W. (eds.) British Women's Writing from Brontë to Bloomsbury. Springer, pp. 245-260. ISBN 9783319782256 doi: https://doi.org/10.1007/978-3-31978226-3 Available at https://centaur.reading.ac.uk/79626/

It is advisable to refer to the publisher's version if you intend to cite from the work. See Guidance on citing.

To link to this article DOI: http://dx.doi.org/10.1007/978-3-319-78226-3

Publisher: Springer

All outputs in CentAUR are protected by Intellectual Property Rights law, including copyright law. Copyright and IPR is retained by the creators or other copyright holders. Terms and conditions for use of this material are defined in the End User Agreement.

www.reading.ac.uk/centaur 
Central Archive at the University of Reading

Reading's research outputs online 
Adam Bede and 'the greeen trash of the railway stall': George Eliot and the Lady

Novelists of 1859

\section{Gail Marshall}

In October 1856, Marian Evans Lewes published her anonymous essay 'Silly Novels by Lady Novelists' in the Westminster Review. On 22 September, ten days after finishing this review, George Eliot embarked on her first work of fiction, 'The Sad Fortunes of the Reverend Amos Barton' (Ashton 163). This temporal coincidence means that the essay is most often read as an apprentice's engagement with the contemporary conditions of the craft she aspired to practice; it is also, as Laurel Brake argues, 'a critique of one zone of reading (the popular) by another (higher journalism)' (254). Brake's formulation presupposes an antagonism between popular fiction and the higher journalism. However, the relationship between the two, in Eliot's own fiction, is far from being mutually exclusive. This essay explores the energizing symbiosis between the popular and Eliot's 'higher' aspirations for her first novel, Adam Bede, which was published by Blackwood and Sons in February 1859. It appeared alongside a plethora of what readers of Eliot's essay might recognize as 'silly' novels: books whose ‘drivelling kind of dialogue, and equally drivelling narrative' ('Silly' 316), whose heroines, plots, 'frothiness,' and general implausibility amply fulfil Eliot's criteria for silliness. But Eliot's first novel enacts a dialogue with this fiction and its readers, and shares in, whilst trying to combat, some of popular fiction's key assumptions about readerly behaviour.

As a novelist, Eliot was competing, commercially and in terms of popularity, with the creators of this fiction, those 'lady novelists' whose work, she feared, might 
seem to represent so poor a return on the education of women, and who might also have mis-educated Eliot's potential readers. It is therefore instructive to see how far her own fiction implicitly acknowledges and actually incorporates elements of the popular novel, as well as to examine both how far some of the silly novels by her contemporaries seem to be influenced by the aspirations, both moral and aesthetic, for fiction that Eliot by then had articulated in Scenes of Clerical Life (1857) and her anonymous journalism.

Historicist approaches to Adam Bede, such as Joseph Wiesenfarth's pioneering 'George Eliot's Notes for Adam Bede' (1977), emphasize Eliot's scholarly attention to the time of the novel's setting at the turn of the nineteenth century, but it is also revealing to consider the implications of the novel's moment of publication in 1859, and to read Adam Bede alongside contemporary texts, some of which have come fundamentally to inform our modern sense of 'the Victorians.' We might read Dinah Morris's practice of housework — used, as Margaret Homans has argued, to such effective romantic purpose in the novel (Homans 165) — alongside Mrs [Isabella] Beeton's strictures to the domestic mistress in the first numbers of her Book of Household Management, which were published in 1859, and in which a well-run house is crucial to enticing men back home at the end of the day. We can read Adam Bede and his rise through the ranks from artisan to employer and focus of local authority as an exemplar of Samuel Smiles's prescriptions in Self-Help (1859) for the 'true gentleman', whose humble origins are no barrier, are indeed an incitement, to his social and financial rise. Dinah and Hetty Sorrel's cart ride to the gallows may have informed the journey in a tumbril that Sidney Carton and the young seamstress make to the guillotine in Charles Dickens's A Tale of Two Cities (1859); and in Madame Thérèse Defarge, one of literature's most famous, and certainly the most 
infamous of, knitters we can see a darkly perverted version of Mrs Poyser, who is rarely seen without her needles, and who shares Mme Defarge's spare, febrile energy and physique, and family devotion. To an extent, these are readings enabled by hindsight, and the passage of time which has validated the writings of Smiles, Beeton, Dickens, and Eliot. However, there is also much for the reader of Eliot to gain by looking in more detail at the reading context provided for Eliot's novel in 1859 by other women novelists, the vast majority of whom are no longer read. These texts reveal a set of assumptions about contemporary life and reading practices that Eliot's work seems designed specifically to combat, and with which it had also explicitly to engage. It is of course true that Eliot did not first appear as a woman writer, although 1859 did see her anonymity breached in the aftermath of the notorious claims by Joseph Liggins to have authored Adam Bede. What is crucial, however, is that Evans Lewes knew herself to be a woman writer, and that was a primary determining consideration in how she positioned herself with her publishers, how she employed her narrative voice, and how she knowingly responded to the context established for female-authored fiction by her contemporaries and their publishers.

During 1859 Eliot's correspondence with her own publisher, John Blackwood and his firm, was very largely carried out through the medium of her partner George Henry Lewes, and provides excellent examples of the solicitude and canniness that Lewes employed on her behalf. However, Eliot and Blackwood also corresponded directly about their views of fiction in general, and the specific prospects for Adam Bede. Within this correspondence, we see the pair evolving their own working relationship - often prickly, but sustained by great tact on Blackwood's part - along with an understanding of the status of Eliot's work, the terms for judging its success, and ways of gauging reader responses. Blackwood learns how to manage his 
famously nervous authoress, and she begins to trust to his generosity and his judgement. That judgement shifts and matures as the year progresses, and as the pair jointly interpret how the market responds to Eliot's work.

Shortly before Adam Bede's publication on 1 February, Blackwood and Eliot discussed their expectations for the novel in terms of its 'popularity,' a term which crops up throughout the year in discussion of her work and those of other authors, and whose meaning becomes more complex, in large part because of the terms of Eliot's own success, as the year goes on. On 29 January, Blackwood writes that:

Adam Bede can certainly never come under the class of popular agreeable stories, but those who love power, real humour and true natural description will stand by the sturdy Carpenter [sic] and the living groups you have painted in and about Hayslope. (George Eliot Letters III, 6)

This carefully calibrated praise strikes a note of caution to which Eliot responds in replying that the impression Adam had made upon the Blackwoods: is my best encouragement, and counterbalances, in some degree, the depressing influences to which I am peculiarly sensitive. I perceive that I have not the characteristics of the 'popular author', and yet I am much in need of the warmly expressed sympathy which only popularity can win. (31 January, Letters III, 6)

Eliot articulates here a tension between the popularity of the 'agreeable' writer of popular fiction, one of those 'lady novelists' about whom she wrote so scathingly but knowingly in 1856 , and that deeper popularity, the love of the people, which is rather a characteristic of the affection gained by writing than a generic measure of the fiction itself. Adam Bede recognizes and indeed inhabits the interstices of this tension, frequently referring readers to expectations that will not be met, most notably in its 
famous chapter 17, 'In Which the Story Pauses a Little,' which anchors reader sympathies in the gaps left by the absence of the more customary 'sorrows of heroines in satin boots and crinoline, and of heroes riding fiery horses, themselves ridden by still more fiery passions' (Adam Bede 35). There is also an interesting conflation here between the person of the author and the writing: Blackwood writes of the characteristics of Adam Bede; Eliot writes of herself, which suggests an investment in her fiction which goes beyond the theoretical or financial.

Understanding the qualities of popular fiction that Blackwood thought George Eliot's work lacked at the start of 1859 , requires engagement with some of the popular novels of 1859 alongside which Eliot's would have been read, and consideration of the terms in which they were received. These texts include: M[atilda]. Betham-Edwards's Now or Never, Geraldine Jewsbury's Right or Wrong, Mrs Octavius Freire [Emily] Owen's Raised to the Peerage, Miss [Julia] Pardoe's A Life-Struggle, Mrs Charles J Proby's The Dennes of Daundelyonn, Julia Tilt's Millicent Neville, and Onwards by 'the Author of 'Anne Dysart', 'Rosa Grey', \&c., \&c.' [Christiana Jane Douglas],. Onwards and Right or Wrong appeared alongside Adam Bede at the start of the year, and, along with Raised to the Peerage, were published by Hurst and Blackett, publishers whom Eliot singled out for particular criticism in a letter of 25 February to Blackwood in which she discussed the marketing of her own newly published novel. She had recently been sent a folio of notices by Blackwood's, and writes:

I have not ventured to look into the folio myself, but I learn [from Lewes] that there are certain threatening marks in ink by the side of such stock sentences as 'best novel of the season' or 'best novel we have read for a long while', from such authorities as the Sun or Morning Star or other orb of the newspaper 
firmament - as if these sentences were to be selected for reprint in the form of advertisement. I shudder at the suggestion. Am I taking a liberty in intreating you to keep a sharp watch over the advertisements that no hackneyed puffing phrase of this kind may be tacked to my book? One sees them garnishing every other advertisement of Hurst and Blackett's trash: surely no being 'above the rank of an idiot' can have his inclination coerced by them, and it would gall me as much as any trifle could, to see my book recommended by such an authority as the writer in Bell's Weekly Messenger who doesn't know how to write decent English. I believe that your taste and judgment will concur with mine in the conviction that no quotations of this vulgar kind can do credit to a book, and that unless something looking like the real opinion of a tolerably educated writer in a respectable journal can be given, it would be better to abstain from 'opinions of the press' altogether. I shall be grateful to you if you will save me from the results of any agency but your own - or at least of any agency that is not under your rigid criticism in this matter.

if I am overstepping the author's limits in this expression of my feelings. I confide in your ready comprehension of the irritable class you have to deal with. (Letters III, 25-6)

The following advertisement for Onwards is sandwiched between two other Hurst and Blackett novels, in a half column of ads for their books on page 12 of The Times - the only paper that Eliot and Lewes saw regularly - for 8 January: 


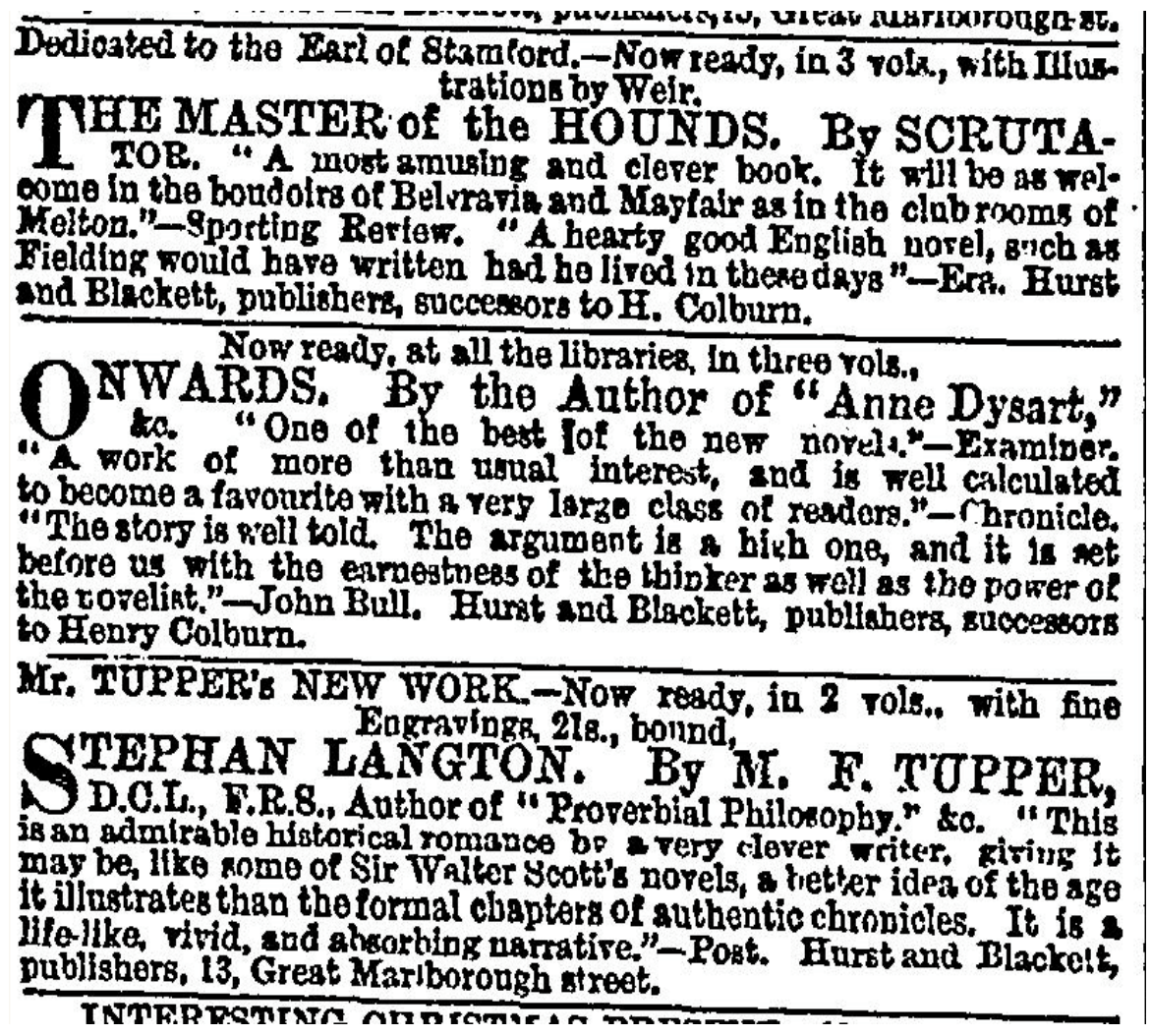

One can easily imagine Eliot's disdain for this egregious puffing, but what was it that

Eliot was objecting to, and the publishers were trying to sell? And how far do these novels fulfil Eliot's categories of 'silly novels'? 'John Bull's' reference to 'the power of the thinker as well as the power of the novelist' seems to threaten Eliot's fictional taxonomies, as does her fear that Blackwood would see her praised in the same terms.

There are of course 'silly' elements in some of these texts: poor - often entirely implausible - plotting and plentiful coincidences, stock characters and hackneyed language, and some of the social and educational pretensions to which Evans Lewes objected in 1856: John Milton is misquoted by Owen, who also notes her heroine's 'touching air of insouciance and reverie upon so young and intellectual a countenance' (Raised to the Peerage I, 238) - a look hard to imagine. She later elevates the English Channel into the "mighty barrier... of hopes and fears to how many hearts; there is the type of the great "once and for ever"' (Raised II, 285). There are, however, fewer of these creative solecisms than one might expect. 
The novels as a whole aim to achieve an authenticated contemporary mode, with significant attention being paid to the details of dress:

The bride wore a dress of rich white moire antique, with flounces of magnificent Honiton lace. Her wreath was composed of orange blossoms and stephanotis; the bridal veil was equally superb as to texture and detail with the flounces, and of the same manufacture; ornaments, pearls. Her travelling costume consisted of a robe of rich brocaded gorge de pigeon silk, mantle and bonnet of costly Brussels point; the latter elegantly trimmed with lilies of the valley. (The Dennes of Daundelyonn vol II, 257-58)

However, the author herself seems to feel a little uneasy about this wealth of detail, and puts it into a fictionalized newspaper account within the novel. This also of course heightens the verisimilitude at which many of these novels aim. Two, for instance, include specific references to Queen Victoria, one novel describing a box at the opera, where 'in her simple, quiet grace, sat England's young and noble Queen' (Millicent Neville II, 229-30). With only one exception, the novels cited above all have contemporary settings, and often refer explicitly to current events and contemporary texts. Millicent Neville, which is concerned very largely, as so many of these novels are, with the challenges of marriage, and not simply with the romance that ends with a wedding, is similarly contemporary in stating:

If women did but know the blessing that follows a soft word or a quiet answer - if their hearts were but filled a little more with tender submissive feelings...how much more of happiness would be found by the domestic fireside, and how much less work would there be cut out for Sir Cresswell Cresswell. (I, 105) 
Cresswell was the first judge in the new Probate, Divorce, and Matrimonial Causes Court, and was noted for his work in the field of divorce law. In The Dennes of Daundelyonn, the eccentric old Miss Crockett finds that 'People are so dreadfully similar nowadays; no originality about them' (I, 173), which is foot-noted in the text: 'Miss Crockett had not the advantage of reading Mr Mill on Liberty.' Published early in 1859, J. S. Mill's On Liberty includes the argument that contemporary society is too much swayed by custom and the customary, which produces a nation of unthinking compliance. Popular fiction may be seen to a significant extent as one of the engines of this compliance.

Class mobility, conflict, and resentments also figure in all these novels, most often in terms of negotiating how characters manage an enforced movement between classes, as in the rising of a woman through marriage, for example, when Millicent Neville's mother, the daughter of a tailor, marries her husband, who was 'then a rather fast young gentleman, lodged in the first-floor' of her house. Subsequently, through 'instruction from her indulgent husband' as to her pronunciation, and 'reading and digesting no end of fashionable novels, procured from a famous circulating library,' Millicent's mother began, according to her sister-in-law, to 'look a little more like other people' (I, 13,14). The need for Mrs Beeton's advice on the achievement of conformity through an aspirational form of domesticity designed to 'restore' or perhaps actually to inculcate domestic and social harmony is made very clear in a number of these novels, where we also see a preponderance of narratives of self-made men rising through the ranks, and prospering by virtue of their intelligence, virtue, and diligence, as recommended by Smiles's Self-Help. 
Nikkianne Moody writes of popular fiction's capacity to engage readers within its 'intense emotional engagement, [and its] licence to pursue what is personally meaningful or culturally relevant' (Moody 128). These novels reveal the day-to-day preoccupations and issues which concerned readers, the anxieties that pressed upon their lives, the terms and forms in which they are expressed, and the ways in which they might be evaded. They also provide insight into the structures that implicitly underpinned the 1850s. Each of the novels carries frequent references to what we call now 'Empire,' but which in these novels is referred to in terms of individual countries, and to the lives of the British and indigenous populations within them. They reveal the practice of referring to the British living in those countries as almost native to that country, so a soldier long stationed in India is referred to as the 'brown Bengalee' (reference) and slave-owning families in the West Indies are called West Indians, and import back into Britain the 'tropical blood' that 'fire[s] up', if they are crossed (Millicent Neville, II, 106). Frequent references to India and Africa embed those regions in contemporary Britain's quotidian life. There is little detail about the relatives who disappear off to India, for example, as no more needs to be said: the word conjures up a set of readily available narratives of the desire for personal exoneration, often mediated through patriotism, that require no explanation. For characters truly in need of a new start, there is America, resort of the black sheep who fall just short of criminality, but who nonetheless need either to escape the respectability of Britain, or to 'retrieve' 'shattered fortunes' (A Life-Struggle I, 9). There is a more raffish edge to those who go west: they go for their own advancement; those who go east may do the same, but their motivation is usually implicated in serving the greater national good. 
Many of the men who leave the country are, like Eliot's Arthur Donnithorne, military men, a character-type which figures largely in novels from this year, as veterans of recent Crimean and Indian campaigns (1853-56 and 1857 respectively), and those of more distant wars, did in society in this belligerent decade. They are invoked as a set of readily available types, not all of whom are admirable. Proby writes of a character that he is:

of the genus Officer; the variety, Dragoon. The order in social ethnology to which he belonged is odious to many persons, yet it has its admirers. The wars in India, China, the Cape of Good Hope and the Crimea, have done much towards altering the tone of military society, and towards morally exterminating the class of which he was a tolerably favourable specimen. (The Dennes of Daundelyonn I, 133)

War is invoked as a form of eugenic machinery, which chimes chillingly with the mechanism of natural selection proposed by Charles Darwin's On the Origin of Species (1859) later in the year. Proby's language of types, of genus and variety, supports that pseudo-scientific reading of her analysis, which is not intended entirely ironically. Belligerence is also expressed through duels, in Adam Bede, where Adam and Arthur duel in the woods belonging to the latter, in A Life-Struggle, as well as in Wilkie Collins's collection of stories, The Queen of Hearts.

Popular texts of 1859 also betray raging anti-Catholicism and an apparently inextinguishable suspicion about the French, who crop up in several novels as the epitome of untrustworthiness, cowardice, and a general lack of English backbone, whether their challenge is crossing the Channel, or struggling with a moral dilemma. There are also, across all types of fiction in this year, illegitimate babies, many of 
whom create far less narrative and social disruption than in Adam Bede, epic journeys on foot, like Hetty Sorrel's, and several true gentlemen in the Smilesian mode, of whom Adam Bede is simply the best-developed example. What might surprise a modern reader familiar with broad narratives of Victorian progress are the number of references to families declining, and bucking the trend of progression. Popular women's writing, with its often minute detailing of how day-to-day life is managed, reveals the burgeoning of a kind of capitalist equilibrium, whereby families who rise are equaled by those, often old landed families, who go into decline. Families run out of energy as new modes of production and money-making challenge their way of life, as is the case with the Donnithorne family in Adam Bede, whose land-owning complacency is usurped by Adam's artisanal entrepreneurship.

Popular women's novels attest to the contemporary preoccupation with these prevalent narrative elements, many of which speak to the hard-felt experience of modernity. But in this fiction's distinctive mode, all is rendered subservient to the impulse to secure an ending sufficiently satisfying to compel into readerly oblivion the tangible complexities previously invoked, to subdue them into simply necessary hurdles in the way of the final amplitude of reader fulfilment.

In many respects the experience of reading Adam Bede could not be further from that of reading Eliot's contemporaries, as her reviewers note. In the Westminster Review, John Chapman writes that '[s]winging on a gate is an intellectual amusement compared with reading most of' 'the crowd of novels which swarm from the press each year' (Chapman 486). In Blackwood's Edinburgh Magazine, W. L. Collins compares Adam Bede with other tales of female preachers and fictional Puritans, and argues that this novel diverges from its contemporaries in its truthfulness: 'in the volumes before us we think we have the genuine article' (Collins 491). Characters are 
drawn not for the effect of the novelty of characters and situations beyond the readers' usual round, but for their ability to broaden readers' sympathies. For the 'general reader' in 'search of entertainment,' Mrs Poyser, an account of whom takes up three pages of the review, might be a favourite character, but this is only one mode of reading and reader. Collins goes on:

It is quite possible that some of those who can devour with satisfaction the green trash of the railway stall, may lay by Adam Bede without much consciousness of having been in unusually good company. But the more thoughtful reader will feel at once that he has been sitting at the feet of a master, that he has been reading a book which, for original power and truth, has rarely been equaled. He will not lay it aside - as is the fate of many a novel of perhaps higher dramatic interest - content with having read and admired it: he will recur it again and again - and each time, we can promise him, with increased delight - to enjoy at leisure its quiet humour, its truthful feeling, its wise and large philosophy. (Collins 501)

The reviewer notes of Hetty: '[t]he one character which, in the hands of many writers, would have been invested with a dangerous interest, awakens in us only a pity nearer to contempt than love' (504). Throughout the review, the spectre of popular fiction lurks as something against which Eliot's novel has to be measured. Anne Mozley's review in Bentley's Quarterly Review reads Adam Bede alongside other newly published fiction, including Anthony Trollope's The Bertrams (1859), and gives over half of its substantial length to Eliot's work, commenting as she embarks upon the rest of the novels that '[a] glance over any chance selection of novels of the day brings out one fact concerning style, that a certain facility belongs to the time without any body or substance to support it...it is surprising with what ease, and even 
promise, a novel will start, which in a chapter or two degenerates into the most vapid extravagance' (Mozley 462). 'Ludicrous,' 'capricious,' 'insipid' and similar adjectives follow in the review of more popular fare, before the review concludes: The insipidity of such [fiction] is felt when a picture of real nature [i.e. Adam Bede] is brought into competition with them, like fresh morning upon a revel. Such a contrast we have welcomed in the impressive tale to which our longest notice has been devoted. (Mozley 472)

The secret of Adam Bede's success, according to Mozley, is that the book 'has a voice of its own which chimes in a telling, because natural and simple, way with associations and thoughts which have been lying half developed and struggling for expression in many minds' (434). Here Mozley proposes an alternative basis for popularity: the novel's revelatory excavation and refamiliarisation of some of the fundamentals of human nature.

The critical tenor of the much slighter reviews of the popular fiction of 1859 makes clear the distance between Eliot and her contemporaries: Millicent Neville is a tale of 'sufferings and their purifying influence...nicely told' whose purpose is 'to show the beauty of unselfish love' ('Literary Examiner,' 13 August 1859); Raised to the Peerage has an 'unduly intricate' plot, and 'probability suffers in order that difficulties may be heaped together and dispersed, and sometimes...there is an irksome toil after fine writing' ('Literary Examiner,' 29 October 1859). Perhaps inevitably the sex of the novelist intrudes, a review of 29 September commenting: “"The Dennes of Daundelyonn" may best be described as an indifferent novel by a clever woman. There is much shrewd sense, knowledge of character, and power of description in its pages, but it contains also gross improbabilities, and wants the unity 
and vraisemblance [despite its up-to-the-minute references] which are necessary to make up a good novel' ( 'Literature'). By this stage in the year perhaps the public had been educated by Eliot to expect more.

To some extent, of course, these novels are straw men to be picked off in a one-sided competition with the might of George Eliot. However, there are notable cross-overs between George Eliot's work and those of her peers which extend beyond the similarities in the plot elements noted above, and her fiction does have more in common with the work of popular 'lady novelists' than many of these reviews, and our own expectations, might allow. (There is even a Squire Donthorne in Onwards, although I have been unable to trace a common root with Eliot's Donnithorne family). Most notably, Eliot's novel is based on a structural trope which underpins all but one of the other novels from the year referred to here: the heroine's choice between a worthy lover (like Adam), and an altogether more dashing and exciting prospect (such as Arthur). Sometimes the heroine gets a new chance at success with the worthier man after the flighty, sexier man has inevitably let her down, sometimes not; Hetty's infanticide, transportation, and death represent by far the most drastic punishment for a wrong choice. Some male characters are more despicable and openly calculating than Arthur, whose fault lies mainly in a selfishly lazy desire to indulge and to be indulged, yet which has results just as devastating as the more malign purposes of cold-hearted, often foreign, seducers. The triangular plot provides the broad narrative structure for all these novels, with the primary difference in Adam Bede being that it is superseded by the story of Dinah and Adam, which attempts finally, though perhaps not entirely successfully, to re-calibrate the text, and shift its centre decisively away from the illicit romance to the hard-won satisfaction of a marriage based in virtue and hard work. 
More surprisingly perhaps, like Adam Bede several of these novels reflect on the form of fiction itself, occasionally indeed echoing Eliot's novel. In Millicent Neville, Julia Tilt writes that: 'There is no need to paint a man blacker than he is. I am not writing a novel portraying model patterns of virtue on the one hand and doubledyed villains on the other. I am simply telling a true story' (Millicent Neville I, 176). This echoes Eliot's treatment of realism in fiction in her review 'The Natural History of German Life' (1856), in chapter 17 of Adam Bede, and in Scenes of Clerical Life. In 'The Natural History of German Life' she writes that 'a picture of human life such as a great artist can give, surprises even the trivial and the selfish into that attention to what is apart from themselves, which may be called the raw material of moral sentiment,' and cites 'opera peasants' as an example of the evil of the unreality of some artists' representations (263). This line of thinking is echoed in Millicent Neville:

[Millicent] knew nothing of poverty, but the name.

Time will show how she bore its actual approach; for poverty-vulgar, disagreeable poverty-was all she had to look forward to.

I often hear people, who have never known any condition but that of wealth, declare they should not mind being poor; but, then, their notions of poverty are mostly gathered from what they see represented at a theatre or opera.

Their notions are of such poverty as resides in pretty little cottages covered with woodbines and roses, with gardens all round them, and blessed with perpetual summer. Not cold, bitter, unromantic poverty (Millicent Neville II, 133-34). 
The conceit is obviously less well-developed than in Eliot, but the approach and its repudiation of 'opera peasants' is clear, and suggests an explicit debt to Eliot's writings.

Eliot's work is, then, embedded firmly in the fictional resources of her moment, critically engaging with, whilst ultimately eschewing, its premises, and also, as reviewers and readers recognized, escaping the constrictions of that moment in which her contemporaries' work is grounded. She does this in large part through appealing beyond the present to what her contemporaries, including Anne Mozley recognized as more fundamental and deep-seated sympathies. As Theodore Martin, husband of the actress Helen Faucit, and later biographer to Prince Albert, writes to Blackwood:

The views of life and character [in Adam Bede]are so large, so Shakspearian [sic] in their breadth of sympathy, the pathos so natural and searching, the humour so genuine, the style so pure, that one almost forgets it is a book and loses himself in the reality of the incidents. It is not often in these days one meets with a book, which furnishes so many points of sympathy. (3 April 1859, George Eliot Letters III, 42)

Jane Welsh Carlyle wrote similarly to Eliot: 'In truth, it is a beautiful most human Book! Every Dog in it, not to say every man[,] woman and child in it, is brought home to one's 'business and bosom,' an individual fellow-creature! I found myself in charity with the whole human race when I laid it down' (20 February 1859, George Eliot Letters III, 18).

Concurring, Lewes observes: 'The book has found its way to the heart of the people as it ought' (13 September 1859, George Eliot Letters III, 152). 
Sympathy has long been recognized both as one of Eliot's major preoccupations and distinctive contributions to the novel genre, but it becomes here the measure of her difference from her contemporaries. Much of that difference rests on, and is enabled by, the novel's historical setting, something which is largely absent from the popular fiction of the year, except occasionally as a picturesque background. (One notable exception is the French revolution, seen in Geraldine Jewsbury's Right or Wrong and most famously in A Tale of Two Cities.) Generally, however, popular fiction is set amidst the concerns and particularities of the present, embedding its readers primarily within an aspirational or escapist rather than an identificatory reading mode, which is clearly less likely to activate sympathy. (Aspiration is at the heart of Beeton's and Smiles's writings too, and clearly also plays a part in Adam Bede, whose hero rises significantly in social standing as the novel progresses. But these modes of aspiration share a rootedness in hard work and application, unlike the more fortuitous and romantically-grounded modes of aspiration in popular fiction.) The significance of Eliot's historical setting goes beyond her incredibly accurate invoking of Britain from 1799-1806; rather history is actually made the vehicle of sympathy.

When she had finished writing Adam Bede, Eliot wrote to William Blackwood: "I have arrived at a faith in the past, but not a faith in the future" (6 May 1859, quoted in McCaw, 121). The novel's imaginative transaction takes place between the late-1850s and the early part of the nineteenth century, and thus exemplifies Eliot's interest in the concept of society as 'incarnate history' (Ashton, ed.284). Within the novel, the community of Hayslope experiences its past as a daily phenomenon, and its present as inseparable from that past. As Mr Irwine notes early in the text, 'the religious benefits the peasant drew from the church where his fathers 
worshipped and the sacred piece of turf where they lay buried' had more to do with their lived qualities than 'a clear understanding of the Liturgy or the sermon' (Adam Bede 63). The vision of the present of 1859, that is, of Adam and Dinah's future, is one that carries its history visibly etched into it as Arthur's past is etched into his saddened face at the end of the novel. As Eliot will go on to articulate more explicitly in The Mill on the Floss (1860), the past and memory form her exemplary characters' moral and emotional foundations, without which they, like Hetty Sorrel, are rendered subject to the whims of romantic desire and wish-fulfilment which are a central part of the currency of popular fiction. In this respect, Eliot departs categorically from the practices of the popular novelists whose example she had consciously derided, but whose fiction hers had echoed in key respects.

As 1859 continues, Eliot recognises in her correspondence that she has somewhat unexpectedly become a popular author. In a letter to her friend and French translator Francois D'Albert-Durade, she makes the distinction between the 'great literary success' of Scenes of Clerical Life, and the 'great popular success' of Adam Bede (Eliot's italics; 18 October 1859, Letters III, 186). John Blackwood describes her to his brother William as 'the most popular author of the day' (30 October 1859, George Eliot Letters, III, 192). The grounds of this popularity are two-fold, and both are acknowledged by Eliot: first, the 'bright fact' that Adam Bede has sold 16,000 copies in one year (5 December 1859, Letters III, 226), and second, the way in which it has entered into people's consciousness, through her writing 'what I love and believe - what I feel to be true and good, if I can only render it worthily' (5 December 1859, Letters III, 227). She is then content to 'leave all the rest to take its chance [...along] with those who are to produce any art that will lastingly touch the generations of men' (5 December 1859, Letters III, 227). All this despite Eliot's and 
Blackwood's fears that the novel was 'too quiet and too unflattering to dominant fashions ever to be very popular' (28 October 1859, Letters III, 191). The number of sales confirms the novel's popularity, but the grounds of its popularity mean that it remains untainted by the more pejorative aspects of that term. Rather, in her igniting of interpersonal sympathies, a new concept of popularity is found in Eliot's novel, whose essence is its activating participatory sympathy, and which has nothing to do with the 'silliness' of lady novelists.

\section{Works Cited}

Ashton, Rosemary. George Eliot: A Life. London: Hamish Hamilton, 1996.

Brake. Laurel. 'The Westminster and Gender at Mid-Century.' Victorian Periodicals Review 33 (2000): 247-71.

[Chapman, John]. 'Adam Bede.' Westminster Review 71 (1859): 486-512.

[Collins, W. L.]. 'Adam Bede.' Blackwood's Edinburgh Magazine 85 (1859): 490504.

Eliot, George. Adam Bede (Oxford: Oxford University press, 2001)

[Eliot, George]. 'The Natural History of German Life' [July 1856] in George Eliot: Selected Critical Writings. Ed. Rosemary Ashton. Oxford: World's Classics, 1992. 260-295.

---. 'Silly Novels by Lady Novelists' [October 1856], in George Eliot: Selected Critical Writings. Ed. Rosemary Ashton, 296-321.

The George Eliot Letters. Ed. Gordon S. Haight. 9 vols. New Haven and London: Yale University Press, 1954-78. 
Freire Owen, Mrs Octavius [Emily]. Raised to the Peerage. 3 vols. London: Hurst and Blackett, 1859.

Homans, Margaret. 'Dinah’s Blush, Maggie’s Arm: Class, Gender, and Sexuality in George Eliot's Early Novels.' Victorian Studies 36 (1993): 155-78.

‘The Literary Examiner,' The Examiner, 13 August 1859. 516.

'The Literary Examiner,' The Examiner, 29 October 1859. 692.

'Literature,' The Morning Chronicle, 29 September 1859. 7.

McCaw, Neil. George Eliot and Historiography: Imagining the National Past. Basingstoke: Macmillan, 2000.

Moody, Nikkianne. 'Defending Female Genius: The Unlikely Cultural Alignment of Marie Corelli and Ouida.' Ouida and Nineteenth-Century Popular Cultures. Ed. Jane Jordan and Andrew King. Aldershot: Ashgate, 2013. 109-28.

Mozley, Anne. 'Adam Bede and Recent Novels.' Bentley’s Quarterly Review 1 (1859): 433-72.

Pardoe, Miss [Julia]. A Life-Struggle. 2 vols. London: Booth, 1859.

Proby, Mrs Charles J. The Dennes of Daundelyonn. 3 vols. London: Smith, Elder, 1859.

Tilt, Julia. Millicent Neville. 2 vols. London: Booth, 1859.

Wiesenfarth, Joseph. 'George Eliot's Notes for Adam Bede.' Nineteenth-Century Fiction (1977): 127-65. 